$\xi=-1$

\title{
Prifacounter: The innovation of traffic counter application for android OS
}

\author{
Prima J. Romadhona ${ }^{1 *}$ and Faizul Chasanah ${ }^{2}$ \\ ${ }^{1,2}$ Civil Engineering Program, Faculty of Civil Engineering and Planning, Islamic University of Indonesia \\ *Corresponding author E-mail: prima_dhona@uii.ac.id
}

\begin{abstract}
In civil engineering, particularly in the field of traffic engineering, it was possible to measure traffic performance by way of surveying the traffic flow, velocity, and density. The current traffic survey is commonly conducted by surveyor who manually calculates the movement of mode of transportation using traffic counter and survey form. Such method was definitely way too costly and time consuming in rendering the traffic data. Therefore, this study aims was to create application design products for technology retrieval and vehicle traffic count calculations, as well as traffic behavior analysis. This research was used Research and Development (R \& D) method. The data accuracy was maintained through check and control to make sure that the inputted data were precisely the same with the results of the display on the application. This application called PRIFACOUNTER that can be operated personally in android OS hand phone. On the basis of the research, it was revealed that some variables and steps in the application concept were definitely needed to determine traffic behavior consisting of traffic flow, capacity, and degree of saturation. Since anyone can use this application, it will reduce the time in order to analyze the traffic performance.
\end{abstract}

Keywords: Traffic Flow; Degree of Saturation; Capacity, Application Technology

\section{Introduction}

Knowing the degree of traffic performance was highly essential in an attempt to overcome wide array of traffic problems ranging from congestion, density, and so forth. One of the benchmarks in measuring the performance of traffic flow is the classification of vehicles. The current traffic survey was commonly conducted by surveyor who manually calculates the movement of mode of transportation using traffic counter and survey form. Such method was definitely way too costly and time consuming in rendering the traffic data.

In addition, various problems may arise when the surveyor works on the counting of the number of vehicles to obtain traffic flow data. Thus, to help curb the existing problems, the researchers aim was to create a vehicle traffic count calculation application for all types of vehicles, especially located in Indonesia. Prior to the designing process, it was necessary to figure out some required variables so that the menu in the data application can help surveyors and technology users at its best, especially on smartphones or PC tablet with android operating system. Afterwards, the researcher was creating android application concepts to calculate vehicle number in traffic surveys, road capacity, and degree of saturation.

\section{Traffic survey methods}

Yulianto and Yuliansya (1) articulated that based on observations in the current land traffic lane, the process of calculating the vehicle at the traffic system was done manually by using the mechanical counter or handy counter. In addition, the data was stored in the logbook. More often than not, such manual process triggers problems in the calculation process, as this process requires good agility and physical condition to obtain an accurate data.

Batra and Sarode (2) said that the survey of traffic was very important component to make a comprehensive transportation study. There are two methods to conduct a traffic volume such as manual method and automatic method. The manual method should conduct with visual counts by the surveyors that were very waste of time. The manual methods usually used to find some data for determination of vehicle classification, vehicle occupancy, turning movements, direction of travel, or pedestrian movement. In the other hand, there are many devices and software available for automatic method of traffic survey. Automatic methods are typically used to find data for determination of daily or seasonal variation and growth trends or annual traffic estimates, and vehicle hourly patterns.

\section{Traffic counter application development}

Yulianto and Yuliansyah (1) was also stated that vehicle traffic counting systems utilizing RFID are able to process information stored automatically to analyze congestion. Thus, in this study, the system was designed to calculate vehicles automatically by utilizing Radio Frequency Identification (RFID) technology. Vehicles are identified using radio waves radiating from the RFID reader and then transponder code of RFID will be processed into the information required by the application user.

In a similar vein, Zhao, Garrick (3) were pronounced that a computer program was indispensable for the automated average annual daily traffic (AADT) calculation process. Traffic Count Analysis System (TCAS) was developed for automated data calculations in the process of calculating traffic flow on the road. Cooptation data 
was used to calculate the average current flow on the road network and reconciliation data was used to regulate and balance the current flow. TCAS has been tested on the two of the longest highways in Connecticut. The result of using TCAS was more appropriate for sloping road calculation procedure. However, TCAS can significantly reduce the time and labor requirements for data traffic volume processing on the road.

Moreover, Sutjiadi, Setyati (4) were asserts that in order to calculate traffic density optimization can be made on the use of video files recorded from CCTV cameras for visual observation and traffic density calculator. The method used in this research was adaptive background extraction with Gaussian Mixture Models Algorithm. This method was acts as an alternative to get data from traffic density with sufficient accuracy as one of the aspects to the process of decision making in traffic engineering.

On this account, Suh and et al (5) were reveals that there was only handful research to ensure the quality of "ground truth" data in which automated technology computation results can be compared. An android tablet based on manual traffic counting application was developed to solve the problem of collecting traffic data, based on manual ground truth data counts.

Unlike other manual counting apps, this app allows data collectors to play back and switch through video in the surveillance mode to redisplay and make correction. The verification of the highway traffic video system around Metro Atlanta was calculated and recalculated using the application function. The number of preliminary and redisplay counts were compared to assess improvements in the calculation accuracy resulted from the redisplay process.

On the basis of the research, it was revealed that the redisplay process lead to significant benefits. It was also pinpoints the fact that this application has the potential to minimize human error and provide more accurate traffic flow data in transportation planning applications and model verification.

One of an automated tool counter was found and better known as Plato (6). PLATO was a technology that can calculate the number of vehicle flow which can type automatically. This innovation was created to address the difficulties experienced by road operators, especially at the road construction planning. The currently common place manual calculation was replaced with an advanced technological tool. PLATO enables computerized and automatized system calculation.

On the each installed device, it was possible to generate fact about the number of vehicles and the classification of transportation mode including the average speed. Later, it was expected that PLATO can be used to measure the growth trend of vehicle, traffic characteristic on that area, and fluctuation of traffic variation on certain time. Thus, it was possible to make road construction planning more appropriately based on the mode of transportation used. The advantages of PLATO were as follows.

1. Solely relying on the sun as the source of energy,

2. Moveable,

3. It was able to send data (telemetry) to station with SMS (Short Message System). Moreover, it will apply developed GPRS (General Packet Radio Service) system that can send visual image, and

4. It was able to store unlimited data capacity. It was depends on the progress of storage technology (software disk).

Apart from its advantages, PLATO may still have some drawbacks as follows.

1. It was still need technology of safety device to avoid ornament theft, and

2. Tool installment in the sloping upward area was gives less maximum results since the tool can be broken easily due to land deformation.

Prakash and Tiwari (7) was also describes the new traffic calculation approach as a way to avoid road congestion. This approach also suggests the best path selection algorithm for vehicles in terms of reduced travel time and less fuel consumption during the trip. The entire traffic management solution was a combination of a "stochastic turn" that the vehicle choose a new pick of a vehicle at each intersection or other road point. In addition, the planning path of origin and destination of the vehicle was required at the start that guaranteed by the suggested path selection algorithm. The simulation result of this approach was proves the effectiveness of the traffic management scheme in terms of reducing traffic congestion on the road. Afterwards, this scheme was also the best from the aspect of the resources and characteristics of the vehicle network to provide less solid road prediction and also tidy up vehicle traffic flow in high traffic density conditions.

\section{Research Methods}

\subsection{Data collection}

The data were collected based on the systematically designed provisions. This research was used secondary data as the data source for the purposes of application development. The data were the form of frequently used-traffic surveys in the field, emerging constraints during the process of manual data collection of primary surveys, and literature on traffic flow calculation methods.

\subsection{Data Input Analysis}

Analysis was conducted to determine the variables to be included in data input for android applications. Furthermore, data analysis process based on MKJI (8) was needed to be processed, in order to find traffic behavior that was comprised of traffic flow, speed and degree of saturation.

\subsection{Application Testing and Level of Accuracy}

The application product testing starts from the input of the survey data followed by the data input of counted vehicle to generate the traffic behavior data in the form of traffic flow, capacity, and degree of saturation. The description of this survey data was the same as the MKJI survey form (8) ie surveyor data, geometry, and others. The te sting stages of this product was written in utilization manual of traffic survey applications as stated and can be downloaded in the android application and in the website.

Once the technological development product was properly applied, its accuracy was tested. Such accuracy testing was aimed to check and control that the inputted data were the same as the existing display results in the application. An example was to make sure whether the control on the display results of the amount of traffic on the application was equal to the amount of vehicle data inputted manually or not. It was be checked by pressing the button or menu according to the type of vehicle. If the user pressed 5 times on the HV button, the data recapitulation on the application will also show number 5 .

\section{Result and discussion}

\subsection{Input components on android apps}

\subsection{1. $\quad$ Supporting data}

Before conducting a survey of the volume of vehicles, surveyors will be required to include supporting data if they were to calculate the performance of the surveyed road segment. The required input components can be seen in Table 1 below. The data must be collected such as location identification, land use, and geometry, in order to find some factors that influenced the capacity of the road. The answer choices were provided in some criteria to decide the factor number to get the capacity in the survey location.

Table 1: Input of supporting data

\begin{tabular}{|l|l|}
\hline Content Option & Display \\
\hline Survey name & (manual input) \\
\hline Managed by & (manual input) \\
\hline Province & (some options of province names were provided) \\
\hline
\end{tabular}




\begin{tabular}{|c|c|}
\hline Content Option & Display \\
\hline City & $\begin{array}{l}\text { (some options of cities in the previously selected } \\
\text { province were provided) }\end{array}$ \\
\hline Date of survey: & (options of dates were provided) \\
\hline Location & (manual input) \\
\hline Starting time & (hour options were provided) \\
\hline Ending time & (hour options were provided ) \\
\hline $\begin{array}{l}\text { City size (total popula- } \\
\text { tion) }\end{array}$ & $\begin{array}{l}\text { (the choices of population range were provided } \\
\text { (millions population) } \\
\text { a. }<0,1 \\
\text { b. } 0,1-0,5 \\
\text { c. } 0,5-1,0 \\
\text { d. } 1,0-3,0 \\
\text { e. }>3,0\end{array}$ \\
\hline $\begin{array}{l}\text { Type of Road and di- } \\
\text { rection separation }\end{array}$ & $\begin{array}{l}\text { Type of Roads with the proportion of direction } \\
\text { separations were given: } \\
\text { a. } 2 / 2 \text { UD } \\
\text { b. } 4 / 2 \text { D } \\
\text { c. } 4 / 2 \text { UD } \\
\text { d. One way }\end{array}$ \\
\hline $\begin{array}{l}\text { Width of shoulders } \\
\text { (m) }\end{array}$ & $\begin{array}{l}\text { Given options: } \\
\text { a. } 0,5 \\
\text { b. } 1 \\
\text { c. } 1,5 \\
\text { d. } 2,0\end{array}$ \\
\hline Road barrier & $\begin{array}{l}\text { Given Options : } \\
\text { a. Shoulder } \\
\text { b. Curb } \\
\end{array}$ \\
\hline Side barriers & $\begin{array}{l}\text { Some classes of side barriers were given: } \\
\text { a. very low: Housing area, almost no activities } \\
\text { b. low: Settlements, some public transports, etc. } \\
\text { c. medium: Industrial area with street-side } \\
\text { shops } \\
\text { d. high : Commercial areas with high side road } \\
\text { activity } \\
\text { e. very high : commercial area and activity of } \\
\text { the road side market was very high }\end{array}$ \\
\hline Number of surveyors & $\begin{array}{l}\text { Given options: } \\
1 \text { to } 20\end{array}$ \\
\hline Width per lane (m) & $\begin{array}{l}\text { Given options: } \\
\text { a. } 3 \\
\text { b. } 3,25 \\
\text { c. } 3,5 \\
\text { d. } 3,75 \\
\text { e. } 4 \\
\text { f. } 5 \\
\text { g. } 6 \\
\text { h. } 7 \\
\text { i. } 8 \\
\text { j. } 9 \\
\text { k. } 10 \\
\text { l. } 11\end{array}$ \\
\hline
\end{tabular}

\subsubsection{Collection of data on traffic volume and compo- sition}

The number of vehicle was collected based on the type of vehicles. On this application, the type of vehicles classified with heavy vehicle/HV (vehicle with passenger capacity more than 8 or vehicle with heavy load), Light Vehicle/LV (vehicle with passenger capacity equal or less than 8 or vehicle with light load), (motorcycle/MC (two-three wheels motorized vehicle), The display of the data capture volume and the composition of the traffic on the application can be illustrated in Figure 1 below.

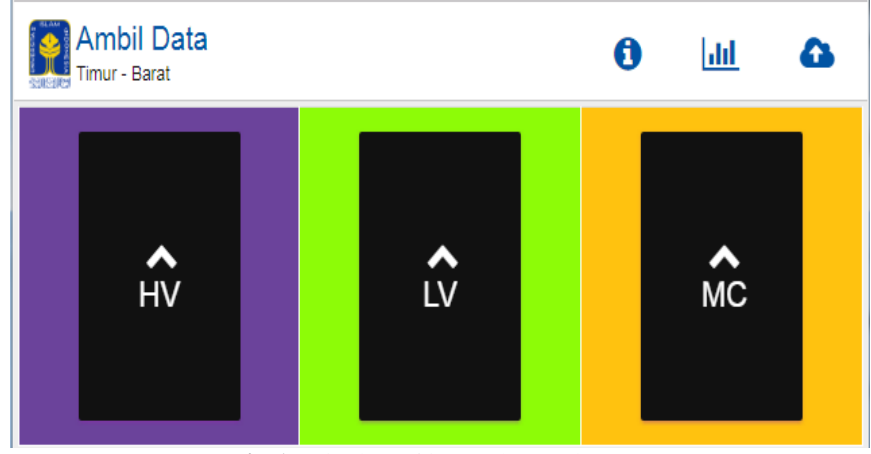

Fig 1: Display of input data volume

\subsection{Method of analysis of urban road performance}

Some steps were taken in the urban road performance analysis that illustrated in the flow chart in Figure 2 below. First of all, at step A required input data such as road geometry, survey data, then volume and composition of traffic. The data was asked by the android apps in the first step. Furthermore, the application will read and analysis the input data at the step A to find some adjustment of capacity and the basic capacity in order to calculate the capacity at the field condition. In the end, calculation of traffic input at the step A was appeal with number of capacity at step B to get the number of traffic performance (saturation degree).

\begin{tabular}{|c|c|}
\hline STEP & A: INPUT DATA \\
\hline A-1: & $\begin{array}{l}\text { General Data: General condition, road geometry, side } \\
\text { barriers }\end{array}$ \\
\hline A-2: & Survey Data \\
\hline A-3: & Volume and composition of traffic \\
\hline & $\downarrow$ \\
\hline STEP & B: CAPACITY \\
\hline B-1: & Basic Capacity \\
\hline B-2: & Adjustment Factor for width of traffic lane \\
\hline & Adjustment factor for direction separation \\
\hline $\begin{array}{l}\text { B-4: } \\
\text { barriers }\end{array}$ & Adjustment factor for the condition of the side \\
\hline B-5: & Adjustment factor for city size \\
\hline B-6: & Capacity at the field condition \\
\hline & \\
\hline & \\
\hline $\begin{array}{l}\text { STEP C: } \\
\text { C-1: }\end{array}$ & $\begin{array}{l}\text { TRAFFIC BEHAVIOR } \\
\text { Saturation Degree }\end{array}$ \\
\hline
\end{tabular}

Fig 2:. Flow Chart of the calculation analysis of urban road segment performance

\subsubsection{Step A: Input Data}

Step A1: General Data

As shown in Table 1, there was a function to be used in the analysis of location identification data as well as for calculation of capacity analysis. The designation of each point was as follows.

1. Segment identification data : points 1 through 8

2. Data for the city size adjustment factor : point no.9

3. Data for the separation of direction factor: point no. 10

4. Data for traffic width adjustment factor : point no.11

5. Data for side barrier adjustment factors : point no. 12 to 13

Sample of the data input can be seen in Table 2 below.

Table 2: Sample of data input

\begin{tabular}{|l|l|}
\hline Content option & Data Input \\
\hline Name of survey & $\begin{array}{l}\text { Traffic Impact of Prawirotaman Traditional } \\
\text { Market }\end{array}$ \\
\hline Managed by: & Prima \\
\hline Province: & DI Yogyakarta \\
\hline
\end{tabular}




\begin{tabular}{|l|l|}
\hline Content option & Data Input \\
\hline City: & Yogyakarta \\
\hline Date of survey: & 15 Mei 2017 \\
\hline Location & Parangtritis Street \\
\hline Starting time & 06.00 \\
\hline Ending time & 09.00 \\
\hline $\begin{array}{l}\text { City size (number of popu- } \\
\text { lation): }\end{array}$ & $1-3$ million people \\
\hline $\begin{array}{l}\text { Type of Road and direction } \\
\text { separation }\end{array}$ & $2 / 2$ UD \\
\hline Shoulder width (m) & 1 \\
\hline Roadblock & Shoulder \\
\hline Side barrier & $\begin{array}{l}\text { very high : Commercial area with high } \\
\text { activity of road side street }\end{array}$ \\
\hline Number of surveyors & 4 \\
\hline Width per Lane $(\mathbf{m})$ & 4 \\
\hline
\end{tabular}

\section{Step A2: Survey Data}

Survey data was the identification for the name of the surveyor who responsible for the input data and the direction of the path to survey.

1. Name of Surveyor: Prima

2. Direction options: South - North

Step A3: Traffic Volume and Composition

This step was to record and reduce data input of the flow and traffic composition. After conducting a survey of traffic flow calculations, the data was displayed in units of vehicles / 15 minutes. Examples of calculations and appearance can be seen in Table 3 below.

Table 3. Example of recapitulation of traffic survey in vehicle / 15 minutes

\begin{tabular}{|l|l|l|l|}
\hline \multirow{2}{*}{ Hour } & \multicolumn{2}{|l|}{ Vehicle Type } \\
\cline { 2 - 4 } & Heavy Vehicle & $\begin{array}{l}\text { Light Vehi- } \\
\text { cle }\end{array}$ & Motorcycle \\
\hline $\mathbf{0 6 . 0 0 - 0 6 . 1 5}$ & 6 & 57 & 461 \\
\hline $\mathbf{0 6 . 1 5 - 0 6 . 3 0}$ & 8 & 62 & 656 \\
\hline $\mathbf{0 6 . 3 0 - 0 6 . 4 5}$ & 3 & 72 & 693 \\
\hline $\mathbf{0 6 . 4 5 - 0 7 . 0 0}$ & 4 & 75 & 592 \\
\hline $\mathbf{0 7 . 0 0 . 0 7 . 1 5}$ & 3 & 39 & 626 \\
\hline $\mathbf{0 7 . 1 5 - 0 7 . 3 0}$ & 5 & 55 & 639 \\
\hline $\mathbf{0 7 . 3 0 - 0 7 . 4 5}$ & 6 & 58 & 610 \\
\hline $\mathbf{0 7 . 4 5 - 0 8 . 0 0}$ & 9 & 82 & 390 \\
\hline $\mathbf{0 8 . 0 0 - 0 8 . 1 5}$ & 13 & 64 & 468 \\
\hline $\mathbf{0 8 . 1 5 - 0 8 . 3 0}$ & 9 & 59 & 401 \\
\hline $\mathbf{0 8 . 3 0 - 0 8 . 4 5}$ & 4 & 69 & 420 \\
\hline $\mathbf{0 8 . 4 5 - 0 9 . 0 0}$ & 2 & 61 & 415 \\
\hline
\end{tabular}

The above data then reconstructed to make the accumulated scheme of vehicles with units of vehicles / hour with the difference of each data per 15 minutes. Examples of calculations and its display can be seen in Table 4 at the follows.

Table 4: Example of recapitulation of traffic survey in vehicle / hour

\begin{tabular}{|c|c|c|c|c|}
\hline \multirow[b]{2}{*}{ Hour } & \multicolumn{3}{|c|}{ Vehicle Type } & \multirow[t]{2}{*}{$\begin{array}{l}\text { Total (Vehi- } \\
\text { cle/Hour) }\end{array}$} \\
\hline & $\begin{array}{l}\text { Heavy } \\
\text { Vehi- } \\
\text { cle }\end{array}$ & $\begin{array}{l}\text { Light } \\
\text { Vehi- } \\
\text { cle }\end{array}$ & $\begin{array}{l}\text { Motorcy- } \\
\text { cle }\end{array}$ & \\
\hline $06.00-07.00$ & 21 & 266 & 2402 & 2689 \\
\hline $06.15-07.15$ & 18 & 248 & 2567 & 2833 \\
\hline $06.30-07.30$ & 15 & 241 & 2550 & 2806 \\
\hline $06.45-07.45$ & 18 & 227 & 2467 & 2712 \\
\hline $07.00-08.00$ & 23 & 234 & 2265 & 2522 \\
\hline 07.15 - 08.15 & 33 & 259 & 2107 & 2399 \\
\hline $07.30-08.30$ & 37 & 263 & 1869 & 2169 \\
\hline $07.45-08.45$ & 35 & 274 & 1679 & 1988 \\
\hline $08.00-09.00$ & 28 & 253 & 1704 & 1985 \\
\hline
\end{tabular}

The recapitulation data with unit of vehicle / hour should equivalent to PCU/ hour based on the requirement of Bina Marga 1997. As the example if the survey was located in Parangtritis Road with undivided type of road (2/2 UD) and the accumulated data lead to total traffic flow of both direction $\geq 1800$ vehicle / hour, the the PCU (Passanger Car Unit) value for HV was 1.2 and MC was 0.35.
On the basis of these provisions, the sample calculations can be seen in Table 5 below.

Table 5. Example of recapitulation of traffic survey in PCU / hour

\begin{tabular}{|l|l|l|l|l|}
\hline \multirow{2}{*}{ Hour } & \multicolumn{3}{|l|}{ Vehicle Type } & \multicolumn{2}{|l|}{$\begin{array}{l}\text { Total } \\
\text { (PCU/Hour) }\end{array}$} \\
\cline { 2 - 5 } & $\begin{array}{l}\text { Heavy } \\
\text { Vehicle }\end{array}$ & $\begin{array}{l}\text { Light } \\
\text { Vehicle }\end{array}$ & Motorcycle & \\
\hline $06.00-07.00$ & 25.2 & 266 & 840.7 & 1131.9 \\
\hline $06.15-07.15$ & 21.6 & 248 & 898.45 & 1168.05 \\
\hline $06.30-07.30$ & 18 & 241 & 892.5 & 1151.5 \\
\hline $06.45-07.45$ & 21.6 & 227 & 863.45 & 1112.05 \\
\hline $07.00-08.00$ & 27.6 & 234 & 792.75 & 1054.35 \\
\hline $07.15-08.15$ & 39.6 & 259 & 737.45 & 1036.05 \\
\hline $07.30-08.30$ & 44.4 & 263 & 654.15 & 961.55 \\
\hline $07.45-08.45$ & 42 & 274 & 587.65 & 903.65 \\
\hline $08.00-09.00$ & 33.6 & 253 & 596.4 & 883 \\
\hline
\end{tabular}

From the foregoing table, it was obvious that Parangtritis road of South-North direction was the busiest time with $1112.05 \mathrm{pcu} /$ hour at 06.45-07.45. These numbers will be used as the basis for the calculation of subsequent traffic behavior. The example of a traffic data display in an application can be seen in Figure 3 below. As stated in the display below, the number of vehicle in each direction was calculated also. It was shown to find the proportion of the flow.

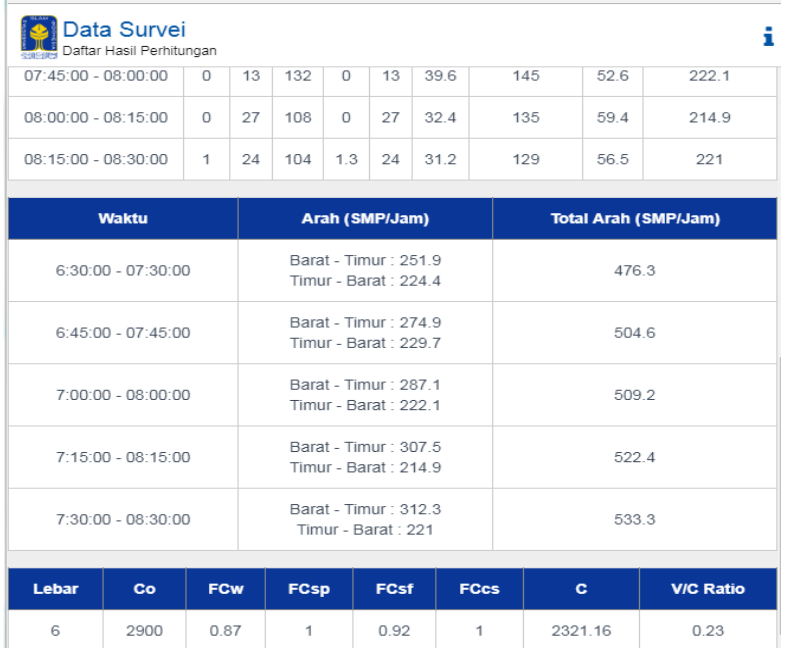

Fig. 3: Example display of traffic calculation on application

\subsubsection{Step B: Capacity}

The capacity was calculated using Ministry of Public Work formulation (8). Based on input data in Table 2, the adjustment factor for capacity calculation can be seen in Table 6 below.

Table 6: Determination of adjustment factor for capacity calculation

\begin{tabular}{|l|l|l|}
\hline Data Input & $\begin{array}{l}\text { Determination of input varia- } \\
\text { ble }\end{array}$ & Quantity \\
\hline $\begin{array}{l}\text { Type of road: Two-lane } \\
\text { undivided }\end{array}$ & Basic Capacity (Co) & 2900 \\
\hline $\begin{array}{l}\text { Type of Road: Two-lane } \\
\text { undivided Road Width: } \\
\text { total: } 8 \mathrm{~m}\end{array}$ & $\begin{array}{l}\text { Capacity Adjustment Factor for } \\
\text { Traffic Lines Influence for } \\
\text { Urban Road (FCW) }\end{array}$ & 1,14 \\
\hline $\begin{array}{l}\text { Type of Road: Two-lane } \\
\text { undivided }\end{array}$ & $\begin{array}{l}\text { Capacity Adjustment Factor for } \\
\text { Direction Separator (FCSp) }\end{array}$ & 0,97 \\
Direction separator: 55-45 & $\begin{array}{l}\text { Capacity Adjustment Factors } \\
\text { Type of Road: Two-lane } \\
\text { undivided }\end{array}$ & 0,79 \\
$\begin{array}{l}\text { Average effective shoul- } \\
\text { der width Ws: 1 m } \\
\text { Side Constraints: Very } \\
\text { Shigh (Commercial Area } \\
\text { with extremely high road } \\
\text { side market activity) }\end{array}$ & $\begin{array}{l}\text { Urban Roads with Road Shoul- } \\
\text { der }\end{array}$ & \\
\hline $\begin{array}{l}\text { City Size (Milion People): } \\
\text { Capacity Adjustment Factor for } \\
\text { City Size (FCCS) on Urban }\end{array}$ & 1,00 \\
Road & \\
\hline
\end{tabular}


Based on Table 6 it was possible to determine the value of field capacity based on Bina Marga 1997 which was calculated as follows.

$\mathrm{C}=\mathrm{C}_{\mathrm{O}} \times \mathrm{FC}_{\mathrm{W}} \times \mathrm{FC}_{\mathrm{SP}} \times \mathrm{FC}_{\mathrm{SF}} \times \mathrm{FC}_{\mathrm{CS}}$

$=2900 \times 1,14 \times 0,97 \times 0,79 \times 1,00$

$=2533,39 \mathrm{PCU} / \mathrm{hour}$

\subsubsection{Step C: Degree of Saturation}

Since the capacity and the flow were calculated previously, it can be found the performance of the road by analysis the degree of saturation. The analysis was below.

$\mathrm{Q}=1112.05 \times 2$ (two way, for this example calculation assuming that North-South was equal to South-North)

$=2224,1$ (pcu/hour)

$\mathrm{C}=2533,39$ (pcu/hour)

$\mathrm{DS}=\mathrm{Q} / \mathrm{C}$

$=2224,1 / 2533,39$

$=0,88$

\section{Conclusions and suggestions}

This application called PRIFACOUNTER that can be operated personally in android OS hand phone. On the basis of the research, it was revealed that some variables and steps in the application concept were definitely needed to determine traffic behavior consisting of traffic flow, capacity, and degree of saturation. Since anyone can use this application, it will reduce the time in order to analyze the traffic performance.

The calculation of traffic flow requires some variables including the type of road, traffic flow/lane with the type of vehicles: motor vehicles, light vehicle/passenger cars, and heavy vehicles. Meanwhile, the calculation of capacity requires some variables including type of road, width of the lane, direction of separator, shoulder width, curbs, and size of the city. The degree of saturation was derived from the division between traffic flow and capacity.

Some steps taken on the concept of this application consist of data input, calculation of traffic flow, capacity calculation, and calculation of degree of saturation. The data input requires general conditions, road geometry, side barriers and survey data. While, the input for traffic flow calculation includes the calculation of cross- ing vehicles in the form of Motorcycle, Heavy Vehicle, and Light Vehicle / Passenger Cars. In addition, the capacity calculation was resulted by multiplying the basic capacity numbers with adjustment factors for the width of the traffic lane, the adjustment factor for the direction separator, the adjustment factor for side barrier conditions, and the adjustment factor for the city size. The concept of traffic behavior calculation application in the form of degree of saturation was resulted by dividing the number of traffic flow with capacity.

It was expected that the upcoming research conduct validation testing by comparing the results of the analysis of the application with the results derived from manual survey. It was also necessary to conduct research for other types of road segments such as highway segments, inter-city roads, intersection and unsignalized intersections.

\section{References}

[1] Yulianto D, Yuliansyah H. Rancang Bangun Aplikasi Traffic Counter RFID. Jurnal Nasional Teknik Elektro dan Teknologi Informasi. 2015; Vol 4, No 1.

[2] Batra U, Sarode MV. traffic surveying and analysis. International Journal of Application or Innovation in Engineering \& Management (IJAIEM). 2013.

[3] Zhao M, Garrick N, Achenie L. Based Traffict Count Analysis System. Journal of the Transportation Research Board. 2014.

[4] Sutjiadi R, Setyati E, Lim R. Adaptive Background Extraction for Video Based Traffic Counter Application Using Gaussian Mixture Models Algorithm. TELKOMNIKA. 2015;Vol.13, No.3.

[5] Suh W, et al. Emerging Data collection methods and Travel Demand models. TRB Annual Meeting2013.

[6] MinistryofPublicWorks. Plato: Automatic Traffic Counters. Research and development Agency of Ministry of Public Works. 2010.

[7] Prakash T, Tiwari R. Counter-based Traffic Management Scheme for Vehicular Networks. Journal of Emerging Trends in Computing and Information Sciences. 2011; Volume 2 No.6.

[8] MinistryofPublicWorks. Manual Kapasitas Jalan Indonesia, Dirjen Bina Marga, Direktorat Bina Kota, Departemen Pekerjaan Umum Republik Indonesia: Direktorat Bina Marga; 1997. 